\title{
Nucleotides of Sugarcane: Increased Nucleotide Content of Leaves as a Function of Nutritional Stress
}

\author{
Alex G. Alexander ${ }^{1}$ \\ INTRODUCTION
}

Sugarcane receiving inadequate amounts of nitrate $(1,2)^{2}$ and calcium $(3,6,12)$ has been shown to accumulate high sucrose levels. During recent experiments in Puerto Rico, plants given progressively lower supplies of $\mathrm{NO}_{3},{ }^{3} \mathrm{P}, \mathrm{K}$, and $\mathrm{Ca}$ all contained more leaf sucrose than those provided with adequate nutrient levels (5). The concept of "physiological stress" is sometimes put forward to account for such increases. Yet the mechanisms by which additional sugar is formed remain obscure.

Initial nucleotide studies at this Station revealed several cane constituents believed to take part in forming sucrose precursors. In particular, the presence of UDPG, adenosine, uridine, and cytidine was noted (4). With such compounds in mind it was theorized that increased nucleotide synthesis might help account for abnormal sucrose levels in nutrient-deficient cane. This paper summarizes recent nucleotide analyses of sugarcane subjected to variable nutrient levels in sand culture.

\section{MATERIALS AND METHODS}

Nucleotide analyses were conducted with leaf tissues of plants which had received decreasing $\mathrm{NO}_{3}, \mathrm{P}, \mathrm{K}$, and $\mathrm{Ca}$ in sand culture over a period of 16 weeks. Details of plant growth and tissue preparation are described in a separate paper (5). At the final harvest of that study the cane was 30 weeks of age, it was receiving zero levels of $\mathrm{NO}_{3}, \mathrm{P}, \mathrm{K}$, and $\mathrm{Ca}$, and was visually expressing the first symptoms of $\mathrm{NO}_{3}$ and $\mathrm{Ca}$ deficiency. Phosphorus and $\mathrm{K}$ nutrition was believed to be well within the zone of "hidden hunger". Nucleotide analyses were confined to samples taken at the final harvest, including those of control plants which were given adequate nutrient levels throughout the study.

Lyophilized leaf tissues, ground in the cold to pass a 60-mesh screen, were extracted with 10-percent trichloroacetic acid in accordance with procedures previously described (4). Nucleotide preparations were chromatographed on anion-exchange columns of Dowex 1-X4, 50-100 mesh and ionic form $\mathrm{Cl}^{-}$.

\footnotetext{
${ }^{1}$ Associate Plant Physiologist, Agricultural Experiment Station, University of Puerto Rico, Río Piedras, P.R.

${ }^{2}$ Italic numbers in parentheses refer to Literature Cited, pp. 236-7.

${ }^{3}$ Abbreviations used herein: Molar, M; ultraviolet, U.V.; uridine diphosphate glucose, UDPG.
} 
Dowex 1-formate columns were prepared by the method of Hurlbert, et al. (7). The following eluting systems were employed with concurrent manual collection of $1 \mathrm{ml}$. of effluent per tube: 1-M sodium formate in $1 N$ formic

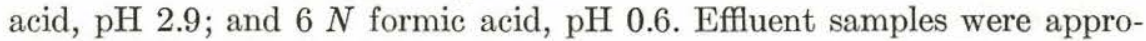
priately diluted and optical density was measured at 260 and $275 \mathrm{~m} \mu$.

Peak U.V.-absorbing fractions were combined and concentrated by lyophilization. Samples were chromatographed on Whatman No. 1 filter paper for more precise analysis of specific nucleotide and sugar constituents. Other samples were analyzed for inorganic P (10) and reducing sugar (14). Organic $\mathrm{P}$ was determined by hydrolyzing samples in $6 \mathrm{~N} \mathrm{HCl}$ at $100^{\circ} \mathrm{C}$. for 100 minutes, and subsequently subtracting inorganic $\mathrm{P}$ values from those of total P.

TABLE 1.-Mean values for leaf sucrose content of immature sugarcane supplied with decreasing concentrations of nitrate, phosphorus, potassium, and calcium in sand culture ${ }^{1}$

\begin{tabular}{|c|c|c|c|c|c|c|c|c|c|c|}
\hline \multirow{2}{*}{ Treatment } & \multicolumn{9}{|c|}{ Milligrams per gram, dry weight, of cane of age indicated (weeks)- } & \multirow{2}{*}{ Mean } \\
\hline & 14 & 16 & 18 & 20 & 22 & 24 & 26 & 28 & 30 & \\
\hline Control & 69 & 63 & 89 & 96 & 89 & 82 & 76 & 80 & 90 & 80 \\
\hline$-\mathrm{NO}_{3}$ & 65 & 75 & 97 & 148 & 116 & 112 & 135 & 123 & 110 & 109 \\
\hline$-\mathrm{P}$ & 67 & 68 & 101 & 132 & 96 & 84 & 78 & 120 & 110 & 95 \\
\hline$-\mathrm{K}$ & 59 & 65 & 94 & 114 & 111 & 115 & 104 & 108 & 117 & 99 \\
\hline$-\mathrm{Ca}$ & 65 & 70 & 111 & 125 & 94 & 87 & 90 & 119 & 141 & 100 \\
\hline Mean & 65 & 66 & 98 & 123 & 101 & 96 & 77 & 110 & 114 & \\
\hline
\end{tabular}

${ }^{1}$ Each figure represents the computed mean of 3 replicates.

Total nucleotide content was measured in terms of O.D.260 units. A reference solution was prepared containing the monophosphates of adenosine, uridine, and cytidine, each at the rate of $0.01 \mu \mathrm{mole} / \mathrm{milliliter}$. One O.D.260 unit gave an optical density reading of 0.22 at $260 \mathrm{~m} \mu$.

Details of all above-mentioned nucleotide procedures are to be found in the earlier paper (4).

\section{RESULTS AND DISCUSSION}

Results verify the theory that nutritional stress is accompained by increased nucleotide synthesis. Evidence suggests that the added nucleotide constituents perform a role in promoting sucrose accumulation.

\section{SUCROSE VS. NUCLEOTIDE CONTENT}

Plants sampled for nucleotide assay had already undergone stepwise reduction of nutrient supply for about 16 weeks. In each instance where $\mathrm{NO}_{3}, \mathrm{P}, \mathrm{K}$, or Ca was withheld, leaf sucrose invariably increased (table 1). 
At the final harvest, when samples were taken for nucleotide analysis, sucrose content was particularly high in low-Ca plants, although both these and low- $\mathrm{NO}_{3}$ plants had already shown abnormally high sucrose some 10 weeks earlier.

Anion-exchange chromatography revealed that leaf nucleotide content was increased in all plants receiving an inadequate nutrient supply (table 2). Nucleotide increases were greatest in the low-Ca and low- $\mathrm{NO}_{3}$ samples, and

TABLE 2.-Analytical data for leaf nucleotides of sugarcane subjected to decreasing nutrient supply in sand culture

\begin{tabular}{|c|c|c|c|c|c|c|}
\hline \multicolumn{2}{|c|}{ Nucleotide- } & \multirow{2}{*}{$\begin{array}{c}\text { Total } \\
\text { nucleotides }{ }^{1}\end{array}$} & \multirow{2}{*}{$\frac{E_{275}}{E_{220}}$} & \multirow{2}{*}{$\begin{array}{c}\text { Reducing } \\
\text { sugar }^{2}\end{array}$} & \multirow{2}{*}{$\underset{\mathrm{P}^{3}}{\text { Inorganic }}$} & \multirow{2}{*}{$\underset{\mathrm{P}^{3}}{\text { Organic }}$} \\
\hline Treatment & Peak No. & & & & & \\
\hline \multirow[t]{4}{*}{ Control } & 1 & 2.7 & 0.83 & 2.95 & 20 & 9 \\
\hline & 2 & 3.6 & .63 & .77 & 301 & 17 \\
\hline & 3 & 60 & 1.02 & .86 & 54 & 82 \\
\hline & Total & 66.3 & 2.48 & 4.58 & 375 & 108 \\
\hline \multirow[t]{4}{*}{$-\mathrm{NO}_{3}$} & 1 & 31 & 0.99 & 3.93 & 29 & 49 \\
\hline & 2 & 2.7 & .83 & .95 & 152 & 8 \\
\hline & 3 & 75 & 1.04 & 1.08 & 125 & 88 \\
\hline & Total & 108.7 & 2.86 & 5.96 & 306 & 145 \\
\hline \multirow[t]{4}{*}{$-\mathrm{P}$} & 1 & 14 & 1.03 & 3.93 & 70 & 47 \\
\hline & 2 & 4.1 & 1.00 & .67 & 136 & 14 \\
\hline & 3 & 81 & 1.04 & 1.12 & 40 & 86 \\
\hline & Total & 91.1 & 3.07 & 5.72 & 246 & 146 \\
\hline \multirow[t]{4}{*}{$-\mathrm{K}$} & 1 & 1.8 & 1.02 & 3.74 & 20 & 15 \\
\hline & 2 & 3.6 & .63 & .72 & 260 & 10 \\
\hline & 3 & 75 & 1.02 & .86 & 100 & 73 \\
\hline & Total & 80.4 & 2.67 & 5.32 & 380 & 98 \\
\hline \multirow[t]{5}{*}{$-\mathrm{Ca}$} & 1 & 3.2 & 1.00 & 2.83 & 40 & 12 \\
\hline & 2 & 5.0 & .82 & .10 & 377 & 0 \\
\hline & 3 & 4.9 & & 77 & 390 & 14 \\
\hline & 4 & 101 & .96 & .88 & 78 & 79 \\
\hline & Total & 114.1 & 3.62 & 4.58 & 885 & 105 \\
\hline
\end{tabular}

${ }^{1}$ O.D.260 units.

${ }^{2}$ Milligrams/milliliter of combined peak fractions.

${ }^{3}$ Milligrams $\times 10^{3}$ per milliliter of combined peak fractions. 
least among plants given low K. In general, two U. V.-absorbing areas were derived from each sample with formic acid-sodium formate ( $\mathrm{pH} 2.9)$, and a single peak with $6 \mathrm{~N}$ formic acid ( $\mathrm{pH} 0.6)$. These peaks are illustrated by figure 1 for control, $\mathrm{NO}_{3}, \mathrm{P}$, and Ca samples. Nucleotide increases for low$\mathrm{NO}_{3}$ and low-P plants are partly accountable to the first peak, which contained vastly greater U.V.-absorbing material than the corresponding peak of control samples. U.V. absorption was also greater in peak No. 3 of
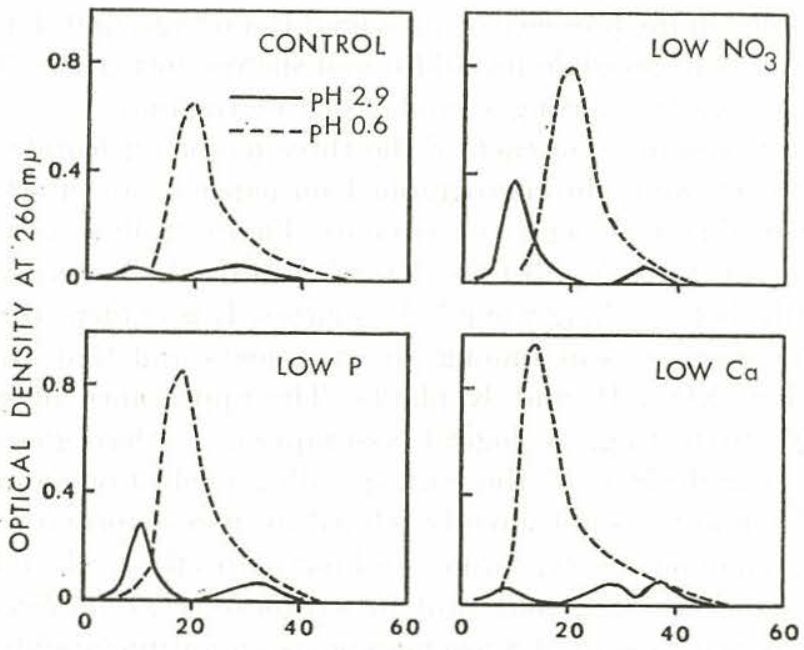

TUBE NUMBER

FIG. 1.-Anion-exchange chromatography of TCA-soluble nucleotides from leaves of sugarcane subjected to nutritional stress in sand culture. Elution with $6 \mathrm{~N}$ formic acid, $\mathrm{pH} 0.6$, followed immediately after collection for tube No. 60 with $\mathrm{pH} 2.9$ formic acid-sodium formate. U.V. readings are superimposed for the two systems to conserve space.

the $\mathrm{NO}_{3}$ and $\mathrm{P}$ samples. Low-Ca plants contained a third peak in the $\mathrm{pH}$ 2.9 elution which was not present among any other treatment (table 2, fig. 1). However, the principal nucleotide increase for low $\mathrm{Ca}$ was obtained in the $6 N$ elution (table 2, Ca peak No. 4).

\section{ANALYSIS OF NUCLEOTIDE FRACTIONS}

Of particular interest was the chemical composition of the enlarged nucleotide peaks induced by low $\mathrm{NO}_{3}$ and low P. Data listed in table 2 show that both treatments caused increased reducing sugar, inorganic $\mathrm{P}$, and organic P. Especially striking was the more than fivefold increase of organic $\mathrm{P}$ in nucleotide peak No. 1. Even in plants no longer receiving $\mathrm{P}$, the or- 
organic P content never dropped below control values, although in such plants a decline of inorganic $\mathrm{P}$ was apparent in peaks 2 and 3.

Assuming that the organic $\mathrm{P}$ constituents included phosphorylated precursors of sucrose, one would strongly suspect that these directly account for much of the additional sucrose observed, and, in fact, this is likely true for the $\mathrm{NO}_{3}$ and $\mathrm{P}$ treatments. Yet low $\mathrm{K}$ and low Ca also increased sucrose without the aid of organic $\mathrm{P}$ accumulations. We surmise then that $\mathrm{NO}_{3}$ and $\mathrm{P}$ stress appear to affect the ratio of organic $\mathrm{P}$ to inorganic $\mathrm{P}$, that organic $\mathrm{P}$ is maintained in the presence of an overall $\mathrm{P}$ shortage, and that whether or not organic $\mathrm{P}$ is responsible for additional sucrose formation, there remain other mechanisms for causing a similar sucrose response.

Concentrated samples of each of the three major nucleotide peaks from every treatment were chromatographed on paper in an effort to identify specific nucleotide and sugar constituents. Figure 2 illustrates fluorescent areas from each peak No. 3 (No. 4 for low Ca) which were visible when scanned with short- or long-wave U.V. sources. It is evident that adenosine and cytidine were present among all treatments and that guanosine appeared in low $\mathrm{NO}_{3}, \mathrm{P}$, and $\mathrm{K}$ plants. The appearance of guanosine is particularly interesting. A logical assumption is that guanosine arose through acid hydrolysis of the corresponding nucleotide (guanylic acid), and that the product is not directly related to sucrose formation. However, a related compound, 8-azaguanine, is known to effectively inhibit amino acid incorporation $(8,9)$, and protein synthesis (11) in Bacillus cereus. Smith and Wheat (13) used 8-azaguanine as an antimetabolite in cultures of Chromobacterium violaceum and greatly increased the synthesis of uridine diphosphomuramyl peptide components. It is possible that the appearance of guanosine in $\mathrm{NO}_{3^{-}}, \mathrm{P}$-, and $\mathrm{K}$-deficient plants reflects a synthesis of an unknown endogenous antimetabolite, which, in turn, promotes the growth retardation characteristic of nutrient-deficient plants.

Figures 3 and 4 illustrate chromatographed sugar components for each of the major U.V.-absorbing peaks derived from treated cane. The major nucleotide peaks (No. 3 or No. 4 in table 2) contained only two sugars for control and low-Ca treatments (Fig. 3). These are tentatively identified as raffinose and stachyose. Raffinose content appeared to be greatly reduced in low-Ca samples. Traces of an unidentified sugar were found in low $\mathrm{NO}_{3}$, $\mathrm{P}$, and $\mathrm{K}$ preparations. Figure 4 reveals a multitude of sugars derived in peaks 1 and 2 (pH 2.9 elution). Fructose, glucose, and sucrose appear consistently for each treatment. Raffinose is also present in each preparation. Traces of three additional sugars were found in varying number, ranging from none in the low- $\mathrm{NO}_{3}$ treatment to three among plants receiving low $\mathrm{P}$ and low $\mathrm{K}$. 
It is concluded that stimulated nucleotide synthesis is a function of nutritional stress in cane. There is little doubt that this contributes to sucrose formation, although specific intermediates are as yet unknown.

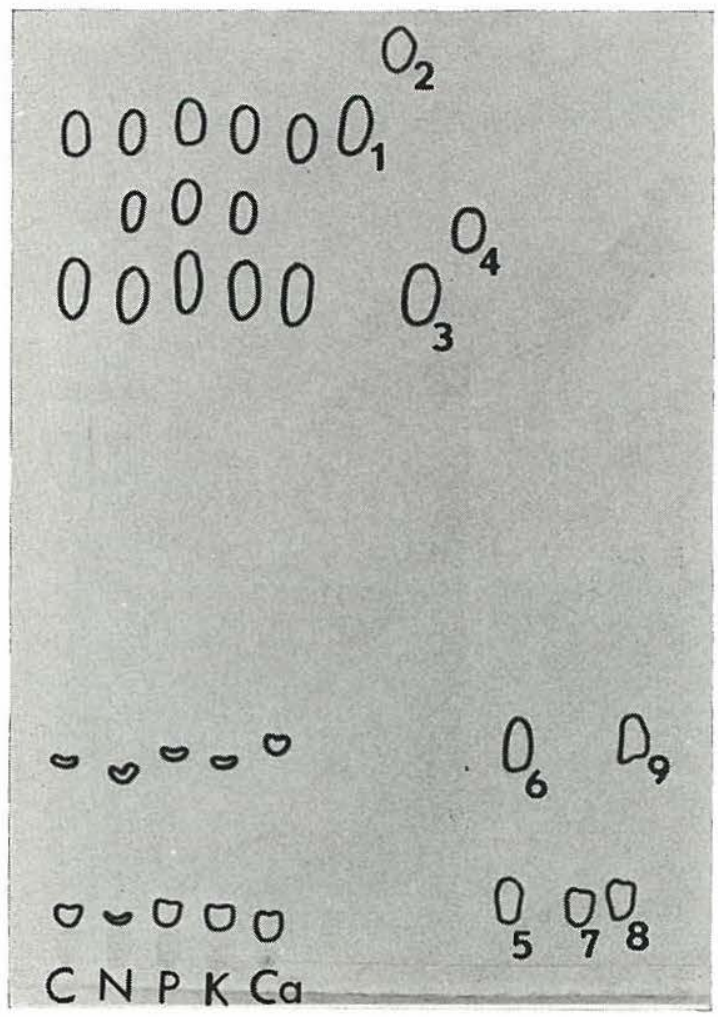

Fig. 2.-Paper chromatogram of nucleosides derived by anion-exchange chromatography of sugarcane-leaf preparations. Nucleosides from the $\mathrm{pH} 0.6$ elution were detected by scanning with short- and long-wave U.V.-light sources. Letters represent the following treatments: $\mathrm{C}=$ control; $\mathrm{N}=$ low nitrogen; $\mathrm{P}=$ low phosphorus; $\mathrm{K}=$ low potassium; and $\mathrm{Ca}=$ low ealcium. Numbers represent $0.01 \mathrm{mg}$. each of the following reference compounds: $1=$ adenosine; $2=$ uridine; $3=$ cytidine $; 4=$ guanosine; $5=$ glucose monophosphate; $6=$ adenosine monophosphate; 7 -uridine monophosphate; $8=$ cytidine monophosphate; $9=$ glucoseamine.

Such concepts could be of use to the sugar industry where interest is high regarding increased sucrose production by use of chemicals or physiological treatments. Stimulated nucleotide synthesis might accomplish this without experiencing tonnage losses of true nutritional deficiency, particularly if the treatment could be effected after maximum growth was attained. 


\section{SUMMARY}

Nucleotide analyses were conducted with sugarcane subjected to decreasing levels of nitrate, phosphorus, potassium, and calcium over a period of 16 weeks in sand culture. In each instance of nutritional stress, abnor-

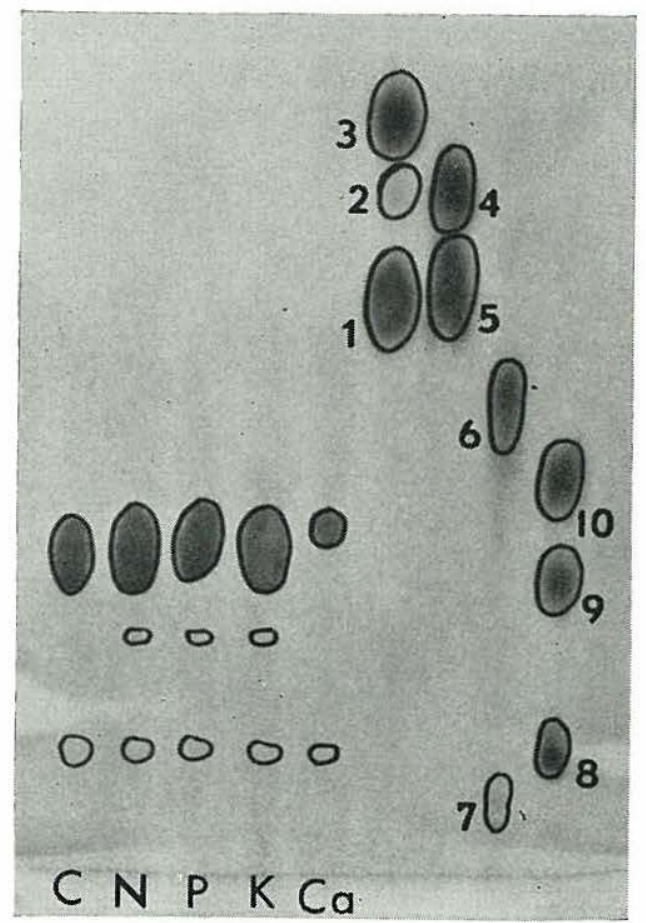

FIG. 3.-Paper chromatogram of leaf-nucleotide preparations from sugarcane subjected to nutritional stress in sand culture. Illustrated are sugar constituents of U.V.-absorbing solutions derived from anion-exchange columns with $6 \mathrm{~N}$ formic acid. Letters represent the following treatments: $\mathrm{C}=$ control; $\mathrm{N}=$ low nitrogen; $\mathrm{P}=$ low phosphorus $; \mathrm{K}=$ low potassium; $\mathrm{Ca}=$ low calcium. Numbers represent $0.04 \mathrm{mg}$. each of the following sugars: $1=$ sucrose $; 2=$ glucose $(0.01 \mathrm{mg}$. $) ; 3=$ fructose $; 4=$ glucose (0.10 mg.) $; 5=$ galactose $; 6=$ glucoseamine, $7=\mathrm{UDPG} ; 8=$ stachyose $; 9=$ raffinose; $10=$ melezitose.

mally high levels of sucrose appeared in leaf tissues. This study was motivated by the theory that abnormal nutritional status might induce added nucleotide synthesis, with the concurrent formation of sucrose precursors.

Lyophilized leaf samples were extracted with trichloroacetic acid, and nucleotide preparations were analyzed by anion exchange plus paper chromatography. Total nucleotide content was higher in each of the near- 
deficient plant sources as compared with those receiving adequate nutrient supply. Nucleotide increase was greatest among low-calcium and lownitrate treatments, and least increase was found in low-potassium samples. Increased nucleotides of low nitrate and phosphorus samples were removed from anion-exchange resins by $\mathrm{pH} 2.9$ formic acid-sodium formate elution.

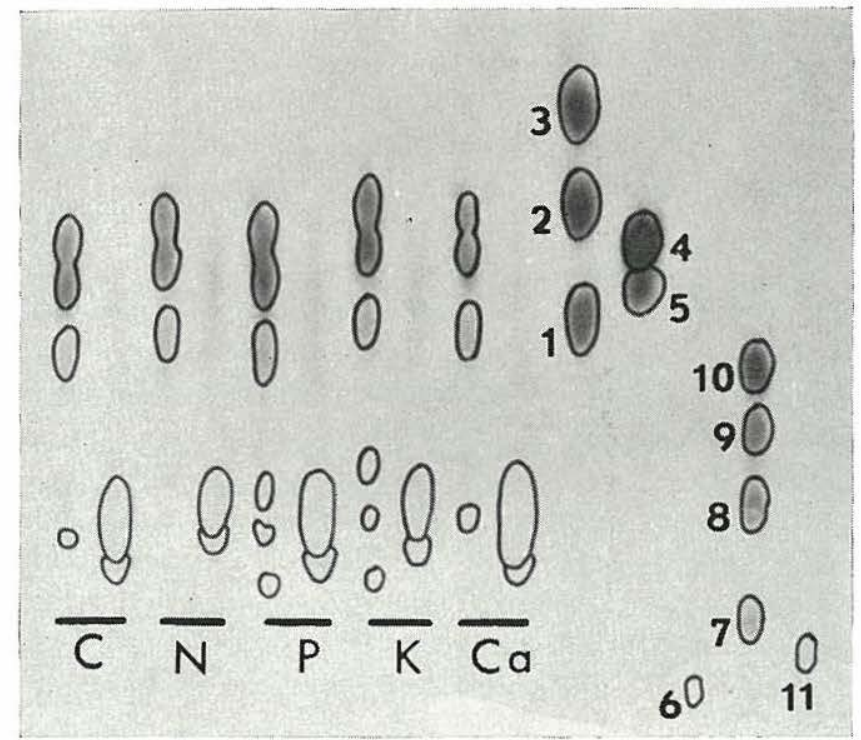

FIG. 4.-Paper chromatogram of leaf-nucleotide preparations from sugarcane subjected to nutritional stress in sand culture. Illustrated are sugar constituents of U.V.-absorbing solutions derived from anion-exchange columns with $\mathrm{pH} 2.9$ formic acid-sodium formate. Letters represent the following treatments: $\mathrm{C}=\operatorname{control} ; \mathrm{N}=$ low nitrate; $\mathrm{P}=$ low phosphorus $\mathrm{K}=$ low potassium; $\mathrm{Ca}=$ low calcium. Numbers represent $0.04 \mathrm{mg}$. each of the following reference sugars: $1=$ sucrose; $2=$ fructose; $3=$ ribose $; 4=$ glucose $; 5=$ galactose $; 6=\mathrm{UDFG} ; 7=$ stachyose $; 8=$ raffinose $; 9=$ melezitose; $10=$ maltose $; 11=$ glucose-1-phosphate.

Low-Ca induced nucleotides were retained at $\mathrm{pH} 2.9$, but were removed from resin columns by $6 \mathrm{~N}$ formic acid.

Nucleotide preparations from nitrate- and phosphorus-treated plants contained high levels of reducing sugar, inorganic phosphorus, and organic phosphorus. More than fivefold increases of organic phosphorus were obtained in both treatments. Low-potassium and low-calcium treatments induced high sucrose without accumulating high organic phosphorus.

The nucleosides adenosine and cytidine were present in all samples. Guanosine was found in nitrate-, phosphorus-, and potassium-deficient 
plants only. The possibility is discussed that an azaguaninelike endogenous antimetabolite is formed as a consequence of nutritional stress, accounting in part for growth retardation and abnormally high nucleotide content.

\section{RESUMEN}

Se analizó el contenido de los nucleótidos en caña de azúcar cultivada en arena y sometida a niveles descendentes de nitrato, fósforo, potasio y calcio durante un período de 16 semanas. En todos los casos en que hubo deficiencia nutritiva, se registraron niveles anormalmente altos de sacarosa en los tejidos foliares. Este estudio se hizo basándose en la teoría de que una condición anormal en el nivel de los elementos nutritivos podría inducir un aumento en la síntesis de los nucleótidos, con la correspondiente formación de los precursores de la sacarosa.

Se obtuvieron extractos con ácido tricloroacético de hojas liofilizadas, y los nucleótidos se analizaron mediante intercambio aniónico y la cromatografía en papel. El contenido total de los nucleótidos fue mayor en las plantas relativamente deficientes en elementos nutritivos, que en las que recibieron una nutrición adecuada. El aumento en los nucleótidos fue mayor en las que recibieron tratamientos bajos en calcio y nitrato, y menor en aquellas con bajas concentraciones de potasio. Los nucleótidos en las muestras bajas en nitrato y fósforo se separaron de la resina de intercambio aniónico mediante una elución con ácido fórmico y formato de sodio a un $\mathrm{pH}$ de 2.9. Los nucleótidos obtenidos de plantas con un bajo contenido de calcio y retenidos a un $\mathrm{pH}$ de 2.9 se separaron de las columnas de resina con ácido fórmico $6 N$.

Las preparaciones de nucleótidos de plantas tratadas con nitrato y fósforo contenían altos niveles de azúcares reductores, fósforo inorgánico y fósforo orgánico. En ambos tratamientos, el fósforo orgánico aumentó más de cinco veces. Las plantas sometidas a tratamientos bajos en potasio y calcio indujeron niveles altos de sacarosa sin acumular altas concentraciones de fósforo orgánico.

En todas las muestras se encontraron los nucleósidos adenosina y citidina. La guanosina se encontró solamente en plantas deficientes en nitrato, fósforo y potasio. Se discute también la posibilidad de que se forme un antimetabolito endógeno parecido a la azaguanina, como resultado de la deficiencia en elementos nutritivos, lo cual explicaría en cierta medida el crecimiento retardado y el contenido anormalmente alto de los nucleótidos.

\section{LITERATURE CITED}

1. Alexander, A. G., Sucrose-enzyme relationships in immature sugarcane as affected by varying levels of nitrate and potassium supplied in sand culture, $J$. Agr. Univ. P.R. 48(3): 165-231, 1964.

2. —- Physiological studies of enzymes catalyzing the synthesis and hydrolysis of 
sucrose, starch, and phosphorylated hexose in sugarcane, J. Agr. Univ. P.R. $49(1): 60-75,1965$.

3. - Induction of varying sugar levels in leaves of immature sugarcane by use of acid phosphatase inhibitors, J. Agr. Univ. P.R. 49(1): 35-59, 1965.

4. - Nucleotides of sugarcane: TCA-soluble and protein-bound nucleotides of sugarcane meristem, J. Agr. Univ. P.R. 51 (3): 210-27, 1967.

5 . - High sucrose levels and abnormal enzyme activity in sugarcane as a function of nutritional stress, J. Agr. Univ. P.R. (In press).

6. Baver, L. D., Report of Committee in Charge of the Experiment Station, Hawaiian Sugar Planter's Association, p. 51, 1944.

7. Hurlbert, R. B., Schmitz, H., Brumm, A. F., and Potter, V. R., Nucleotide metabolism; II, Chromatographic separation of acid-soluble nucleotides, J. Biol. Chem. 209: 23-39, 1954.

8. Mandel, H. G., and Altman, R. L., The depression of the incorporation of sulfur amino acids into Bacillus cereus by 8-azaguanine, J. Biol. Chem. 235: 2929-35, 1960.

9. Mandel, H. G., Effect of 8-azaguanine on utilization of methionine by $B$. cereus, Arch. Biochem. Biophys. 76: 230-2, 1958.

10. Methods of Analysis of the Association of Official Agricultural Chemists, 6th ed., Washington, D.C., pp. 127-8, 1945.

11. Roodyn, D. B., and Mandel, G., The differential effect of 8-azaguanine on cell wall and protoplasmic protein synthesis in Bacillus cereus, J. Biol. Chem. 235: 2036-44, 1960.

12. Samuels, G., and Cibes, H., Influence of mineral deficiencies on the growth and yield of sugarcane, J. Agr. Univ. P.R. 47(2): 61-75, 1963.

13. Smith, E. J., and Wheat, R. W., Intracellular nucleotides isolated from Chromobacterium violaceum, Arch. Biochem. Biophys. 99: 109-15, 1962.

14. Sumner, J. B., Dinitrosalicylic acid, a reagent for the estimation of sugar in normal and diabetic urine, J. Biol. Chem. 47: 5-9, 1921. 